Article

\title{
Environmental Transformations in the Area of the Kuźnica Warężyńska Sand Mine, Southern Poland
}

\author{
Jacek Różkowski, Oimahmad Rahmonov *(D) and Artur Szymczyk \\ Faculty of Natural Sciences, University of Silesia in Katowice, 41-200 Sosnowiec, Poland; \\ jacek.rozkowski@us.edu.pl (J.R.); artur.szymczy@us.edu.pl (A.S.) \\ * Correspondence: oimahmad.rahmonov@us.edu.pl
}

Received: 18 March 2020; Accepted: 8 April 2020; Published: 10 April 2020

\begin{abstract}
On the basis of the analysis and interpretation of maps, published literature, and environmental reconnaissance, this article discusses environmental transformations in the area of the Kuźnica Warężyńska sand mine in southern Poland over the years 1944-2015. A comprehensive ecological analysis was carried out concerning spatial development, mining activity, hydrogeological and hydrological conditions as well as the biotic environment. Among the unfavourable changes found were a drastic reduction in the agricultural function of the area (from 7.03 to $0.47 \mathrm{~km}^{2}$ ), mainly due to periodic activity of sand mine in 1967-2002, covering an area of about $5.80 \mathrm{~km}^{2}$, the destruction of the original biocenoses, the depletion and deterioration in quality of the groundwater resources, and man-made transformations of the hydrographic network (during the mine's activity its length reached over $103 \mathrm{~km}$ ). Vegetation changes during the 70-year period examined were closely related to human mining activity. The greatest changes occurred at the end of the 1960s when large areas of pine forest were cut down. The analysis of vegetation in the former workings demonstrated that the diversity of habitats within the workings results in a significant increase in species (367 plant species, 2002 birds) and community diversity (Molinion caeruleae, Molinion caeruleae, three Natura habitats) there compared to the adjacent areas. On the other hand, favourable changes included the construction of a flood control reservoir, with an area of 560 ha and a volume of 51 million $\mathrm{m}^{3}$, created in 2003-2005, making the area more attractive for tourism and recreation, and an increase in biodiversity, including the establishment of a Natura 2000 site.
\end{abstract}

Keywords: landscape change; hydrogeological transformation; vegetation succession; sand quarry; land use

\section{Introduction}

Opencast mining, which results in the complete disintegration of biocenoses and of the pedosphere, is among the most drastic human impacts on the environment. It involves the removal of vegetation and the destruction of soil cover in the areas where minerals, including sand, are mined. As a raw material, sand is one of the most frequently used mineral resources on Earth [1]. Sand is an important mineral for our society in protecting the environment, buffer against strong tidal waves and storm, habitat for crustacean species and marine organism [2], used for making concrete, filling roads, building sites, brickmaking, making glass, sandpapers, reclamations, and in our tourism industry in beach attractions. Sand mining is the process of removal of sand and gravel where this practice is becoming an environmental issue as the demand for sand increases in industry and construction [3-6]. Currently, owing to the growing demand for mineral resources, the number of degraded and destroyed sites worldwide has increased [7-11], and opencast mining often has irreversible natural consequences. Mineral resource mining has one of the strongest impacts among all industries, distorting the natural environment globally $[12,13]$ and often causing it to lose its ecological functions [14]. 
The regeneration and reclamation of areas degraded by human activity is conditioned by both social and natural aspects. Among the most important factors determining the direction of reclamation is the demand for a specific function for the area in question. It should be stressed that not all degraded areas can be transformed according to such demands, but most of them can be regenerated in a manner which is in line with the existing conditions $[8,15]$. Sustainable regeneration covers economic, social, spatial and environmental aspects [16,17]. It should be carried out in a cost-effective and socially acceptable way, taking long-term effects into account.

The term "reclamation direction" should be understood as the manner in which the area which requires remedial action is ultimately developed. Reclamation of degraded areas is a complex technical process which involves initiating, through targeted measures, the processes that restore functional and natural values to areas transformed by human activity. The reclamation as the process directed for rehabilitation of degraded (and often abandoned) areas to nature involves a number of measures that enable the construction of a new ecosystem [18] or its incorporation into a similar ecological or landscape system which is present in the immediate vicinity. In essence, the purpose of the technical measures implemented is to create or restore a biotope, i.e. inanimate parts of the ecosystem, and also to restore selected components of biocenoses through deliberate planting or the reintroduction of animals $[19,20]$.

Depending on the type of terrain and public demand, former sand workings can be subject to various approaches to their reclamation $[3,4,8]$. In Poland and other European countries, such workings are often transformed into forests or water bodies which then serve recreation, teaching, natural or technical purposes [20-23]. The criteria for selecting the right approaches to reclamation for any single area are determined by economic, formal and legal, geological and engineering, cultural and environmental factors [24].

Former mineral workings in Upper Silesia are often reclaimed by transforming them into artificial lakes. This consists in the construction of a reservoir in the area, which can be used for recreation or fish rearing purposes or perform other functions as part of the biocenosis [16,22,25]. Hydrological and hydrogeological conditions are factors which determine the choice of this approach to the reclamation. The following types of former workings are suitable for this purpose: those which were flooded during extraction, those which had to be drained during extraction and those whose bottom and slopes consist of poorly permeable material. Such water bodies also increase the retention capacity of the area which is important from the point of view of water management [26].

Issues related to the development of former mineral workings are considered in various aspects, including the possibility of transforming them into water bodies. These issues concern the general concept plan for the reclamation, the principles of water management and also the impact of earlier opencast mining on groundwater circulation and water quality $[24,25]$; such considerations guide the reclamation of degraded areas in various parts of Poland [27].

Reclaiming such areas as artificial lakes usually creates new opportunities for nature to expand, especially in areas with poorly developed river networks which are deprived of large natural lakes. A new body of water may significantly enrich the natural environment, improving the landscape or increasing biodiversity [19]. The construction of a reservoir increases retention capacity and habitat heterogeneity; landscape characteristics undergo favourable changes as well. A multifunctional reservoir is created in accordance with the principles of sustainable development, which meets both natural and recreational requirements and boosts tourist traffic in the area, resulting in its economic revival. Such a trend in reclamation is now becoming increasingly popular with local governments, since it is in line with growing public demand and brings measurable economic and environmental benefits.

In Poland, rock materials are extracted in more than 5000 active open mines with a total output of over 250 million tonnes. In Poland, as at 31 December 2018, the number of filling sand deposits totaled 31 deposits with geological reserves of 2515.08 million $\mathrm{m}^{3}$; developed deposits totaled nine deposits with developed reserves of 73.59 million $\mathrm{m}^{3}$; discontinued operation totaled six deposits. The reclamation of former opencast mines is a significant and large-scale environmental problem. Some mineral workings 
are reclaimed by turning them into bodies of water which fulfil recreational, agricultural and ecological functions. Recreational reservoirs have been constructed in, among other places, the Kraków and Kielce areas in former workings where Upper Jurassic limestone (Zakrzówek), sand (Kryspinów), natural aggregates, loam and gravel were once extracted, in the defunct Gacki-Krzyżanowice gypsum mine. In the Szczakowa sand pit, the largest reclamation works of all former mineral workings in Poland were carried out after the extraction of sand had ceased. The reclaimed area exceeds 3000 ha and includes the 55 ha Sosina Reservoir, which was constructed between 1969 and 1972 [9]. The defunct Kuźnica Warężyńska sand pit was situated in the vicinity of the Szczakowa mine.

\section{Materials and Methods}

\subsection{Cartographic Analysis}

The analysis of environmental and land use changes in the area of Kuźnica Warężyńska has been based on the published literature listed in the Literature section, including maps from the years 1944-2015, field observations and environmental reconnaissance.

The maps used included: 1:25,000 (map of Upper Silesian Industrial District sheets from 1986-1988), and 1:100,000 (map of the surroundings of Sosnowiec from 1944) topographic maps [28], a Head Office Geodesy and cartografy (Główny Urząd Geodezji i Kartografii) orthophotomap from 2015, Wojkowice sheet of the Detailed Geological Map of Poland in the scale 1:50,000 from 1957 and Wojkowice sheet of the Hydrogeological Map of Poland in the scale 1:50,000 from 1997; Zawiercie sheet of the Hydrographic Map of Poland in the scale 1:50,000 [29,30]. All topographic maps are available in the Open Regional Spatial Information System (Otwarty Regionalny System Informacji Przestrzennej--ORSIP)_-Geoportal of the Silesian Province [31]. The topographic maps were analysed and interpreted using GIS methods. Sosnowiec topographic map from 1944 and topographic map of the Upper Silesian Industrial District from 1960 were georeferenced in two steps. Firstly, the corner points of the raster image were overlaid onto the grid with a size corresponding to the map frame size using affine transformation. Secondly, rectification was carried out and the image was adjusted to the reference layer using control points [32]. Topographic maps from 1986-1988 and an orthophotomap are available in georeferenced version. The results obtained from orthophotomap (from 2015) have been verified and supplemented in the field.

All cartographic materials were digitized, and errors usually generated during this operation were detected and eliminated [33]. Screen digitization was combined with the creation of a database of land development. Data included in each series of maps were aggregated to make the comparable [34]. As a result, vector maps were created which allowed comparison of land development in particular time sections to be carried out.

The drawings used for interpretation purposes were executed using MapInfo. Indoor analyses were complemented by field studies, which made it possible to determine present trends and examine the current state of development of the former workings in the light of data from various sources.

Data on chemical analyses of water were obtained from articles in the following databases: Polish Hydrogeological Databases [35] and Mining Polish Scientific Bibliography [36].

\subsection{Research on Fauna and Flora}

Long-term floristic, phytosociological and amphibian investigations were conducted in two stages in the years 1994-2010 and 2010-2018. During the research, inventory of flora and fauna were done and also phytosociological documentation were carried out to distinguish vegetation communities. The results of the first stage research from 1994-2010 were used to classify this area in 2011 as a Natura 2000 site. The study also used published results of avifauna studies from 1994-2014 [37], which were supplemented by the results of the authors' observations. 


\subsection{Study Area Characteristics}

The study area is located in the Silesian Province within the Dabrowa Valley $\left(50^{\circ} 22^{\prime} 29.37^{\prime \prime} \mathrm{N}\right.$ $19^{\circ} 12^{\prime} 05.01^{\prime \prime}$ E) which is part of the Silesian Upland (southern Poland) in the catchment of the River Vistula (Figure 1).

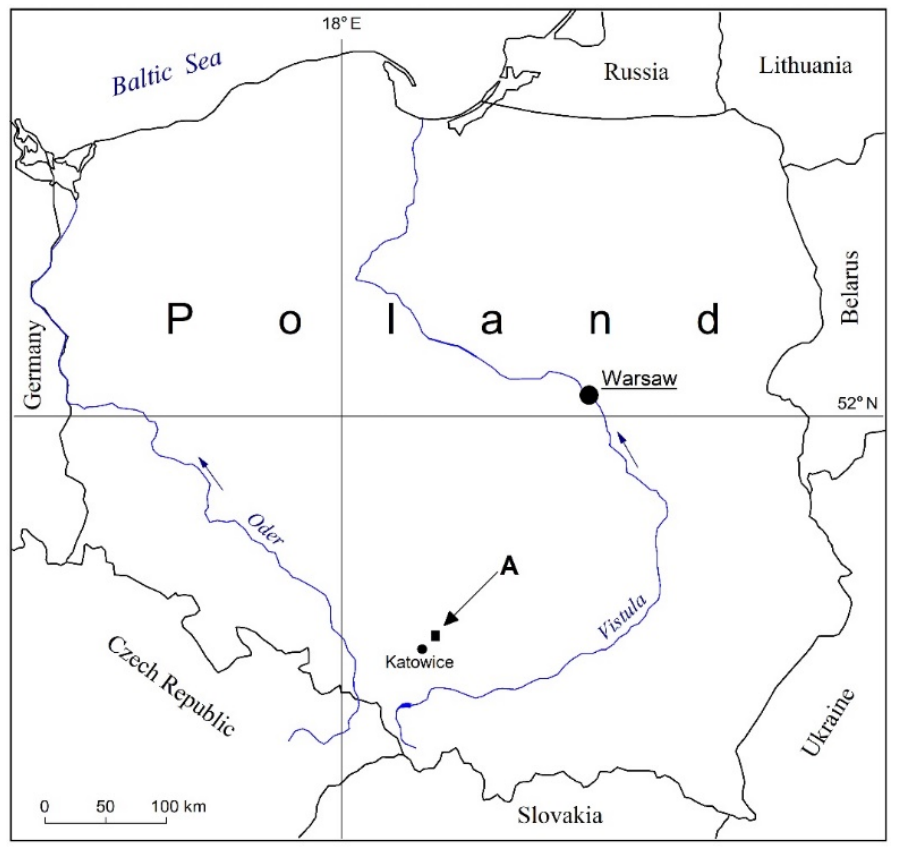

Figure 1. Research area in the geographic context of Poland and Europe.

The eastern part of the Valley is filled with Quaternary sediments: in the valleys of the Czarna Przemsza River and its tributaries there are Holocene fluvial sediments, Pleistocene glacial sands, gravels with some glacial tills, and eolic sands in dunes [30]. The study area is situated on the boundary of two geological units: The Silesian-Cracovian Monocline and the Upper Silesian Depression. The Silesian-Cracovian Monocline is characterized by fold-block tectonics. It is built of Triassic and Jurassic sediments. The Upper Silesian Depression is characterized by block tectonics. It is built of Carboniferous sediments covered with younger Paleozoic and Cenozoic deposits.

The Kuźnica Warężyńska sand mine extracted sand and locally also gravel from 1967 to 2002, operating in four layers within the $12.713 \mathrm{~km}^{2}$ area of its mine ([26] Figure 3). Flooding of the mine working started in March 2002, with pumping stations being gradually shut down in series and water from the Czarna Przemsza River being directed into the open pit. The target filling level of $264 \mathrm{~m}$ a.s.l. a flooded mining pit was reached in November 2006 ([26] Figure 4).

A continuous aquifer was found in the buried valley of the Czarna Przemsza River. This was associated with Quaternary sediments in the form of fluvioglacial fine- and medium-grained sands, with local gravel and rock debris inserts; the underlying layers are impermeable Carboniferous, Permian and Triassic formations. This is an exposed flow-through aquifer, which is highly vulnerable to pollution from the surface.

\section{Results and Discussion}

Human pressure has resulted in the transformation of individual components of the natural environment in the study area: land use, hydrogeological and hydrological conditions, biotic environment, as described below in Sections 3.1-3.6. 


\subsection{Changes in Land Use}

Table 1 and Figures 2-5 show spatial development changes in the Kuźnica Warężyńska area in the years 1944, 1960, 1988 and 2015. The following trends can be observed: the virtual disappearance of arable land, periods of opencast mining from 1967 to 2002, the construction of the reservoir from 2003 to 2005 and rapid urbanisation in the 21st century. The hydrographic network has been changed significantly. In the 1960s, its development was related to natural processes (the increase in meadows and pastures accompanied by a decrease in arable land through the formation of bogs and marshes, the emergence of ox-bow lakes within the valley, drainage work); from the 1970s to the 1990s, the groundwater was drained by opencast mine drainage channels, at the lowest mean elevations of the pit bottom from $+243 \mathrm{~m}$ a.s.l. up to $+249 \mathrm{~m}$ a.s.l. On the eastern side of the Kuźnica Warężyńska Reservoir, a significant area is occupied by former sand workings which are now wasteland as well as by forests. Dense urban and industrial development zones are present mainly along boundaries of the area. The largest areas in 2015 were: water reservoirs $4.88 \mathrm{~km}^{2}$, built-up areas and industrial areas $1.02 \mathrm{~km}^{2}$, meadows and pastures $3.20 \mathrm{~km}^{2}$, forest and groups of trees $4.50 \mathrm{~km}^{2}$ (Table 1).

Table 1. Changes in land use in the area of Kuźnica Warężyńska in the period 1944-2015.

\begin{tabular}{|c|c|c|c|c|}
\hline \multirow{2}{*}{ Land Cover } & \multicolumn{4}{|c|}{ Area in the Following Years $\left[\mathrm{km}^{2}\right]$} \\
\hline & 1944 & 1960 & 1988 & 2015 \\
\hline Water reservoirs & 0.00 & 0.01 & 0.05 & 4.88 \\
\hline spatial development & 0.20 & 0.29 & 0.25 & 0.97 \\
\hline Industrial areas & 0.00 & 0.00 & 0.10 & 0.05 \\
\hline Wastelands & 0.11 & 0.21 & 0.24 & 0.02 \\
\hline Urban greenery & 0.00 & 0.03 & 0.04 & 0.02 \\
\hline Arable land & 7.03 & 2.70 & 2.04 & 0.47 \\
\hline Meadows and pastures & 3.15 & 6.38 & 4.00 & 3.20 \\
\hline Forests and groups of trees & 3.89 & 4.75 & 1.57 & 4.50 \\
\hline Sand pit, sands and beaches & 0.00 & 0.00 & 6.09 & 0.27 \\
\hline Total area: & 14.37 & 14.37 & 14.37 & 14.37 \\
\hline Sum of watercourses lengths $[\mathrm{km}]$ : & 19.96 & 58.54 & 103.29 & 14.73 \\
\hline
\end{tabular}

The most important change in spatial management is therefore periodic mining activity and reclamation of the post-mining area in the water direction. Kuter [38] emphasizes that the ultimate goal of reclamation is precisely sustainably establish the aesthetic and ecological conditions of the post-mining landscape so that it become as much compatible as with surrounding undisturbed lands. Pavlodaukis et al. [39] emphasize the need for public involvement in decision-making involving environmental management of surface mining projects with special emphasis on the Aarhus Convention, an initiative of UN Economic Commission for Europe. 


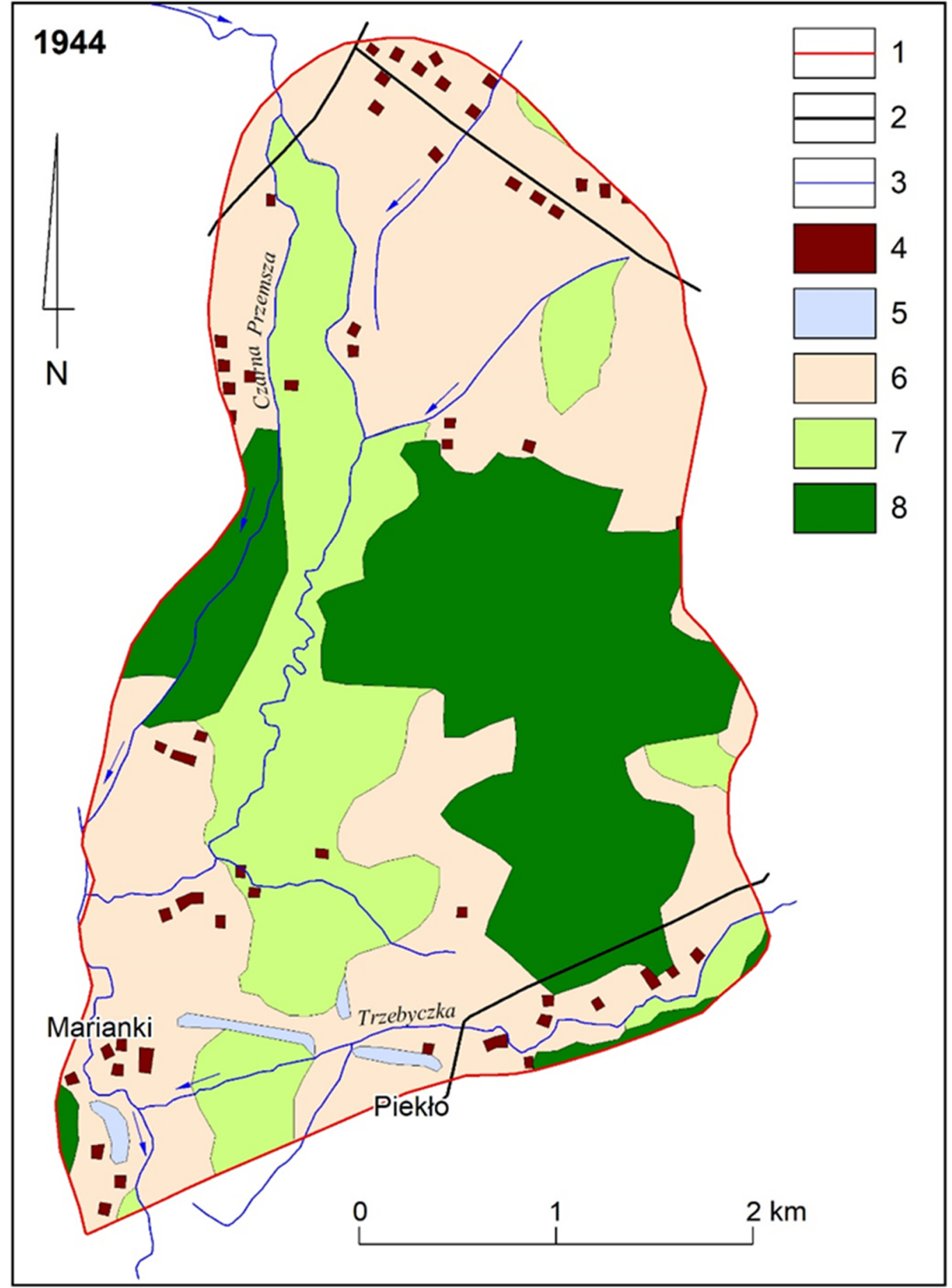

Figure 2. Changes in land use in the area of Kuźnica Warężyńska for the year 1944: 1—border of the research area, 2-important roads and railways, 3-permanent watercourses, 4-spatial development, 5-wastelands, 6-arable land, 7-meadows and pastures, 8-forests and trees (including parks, orchards). 


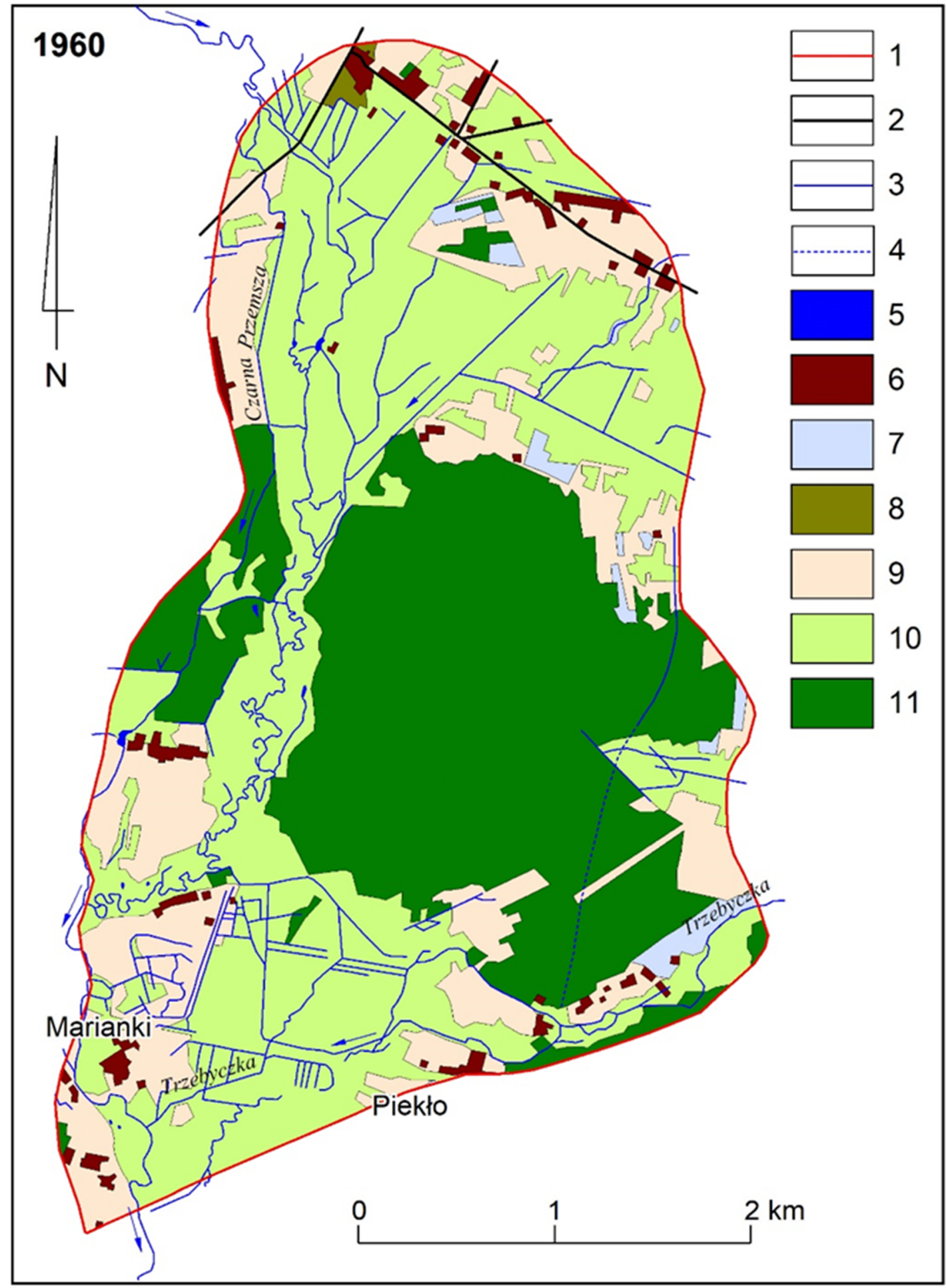

Figure 3. Changes in land use in the area of Kuźnica Warężyńska for the year 1960: 1—border of the research area, 2-important roads and railways, 3-permanent watercourses, 4-periodic watercourses, 5-water reservoirs, 6-spatial development, 7-wastelands, 8-urban greenery (allotments and home gardens), 9-arable land, 10-meadows and pastures, 11—forests and trees (including parks, orchards). 


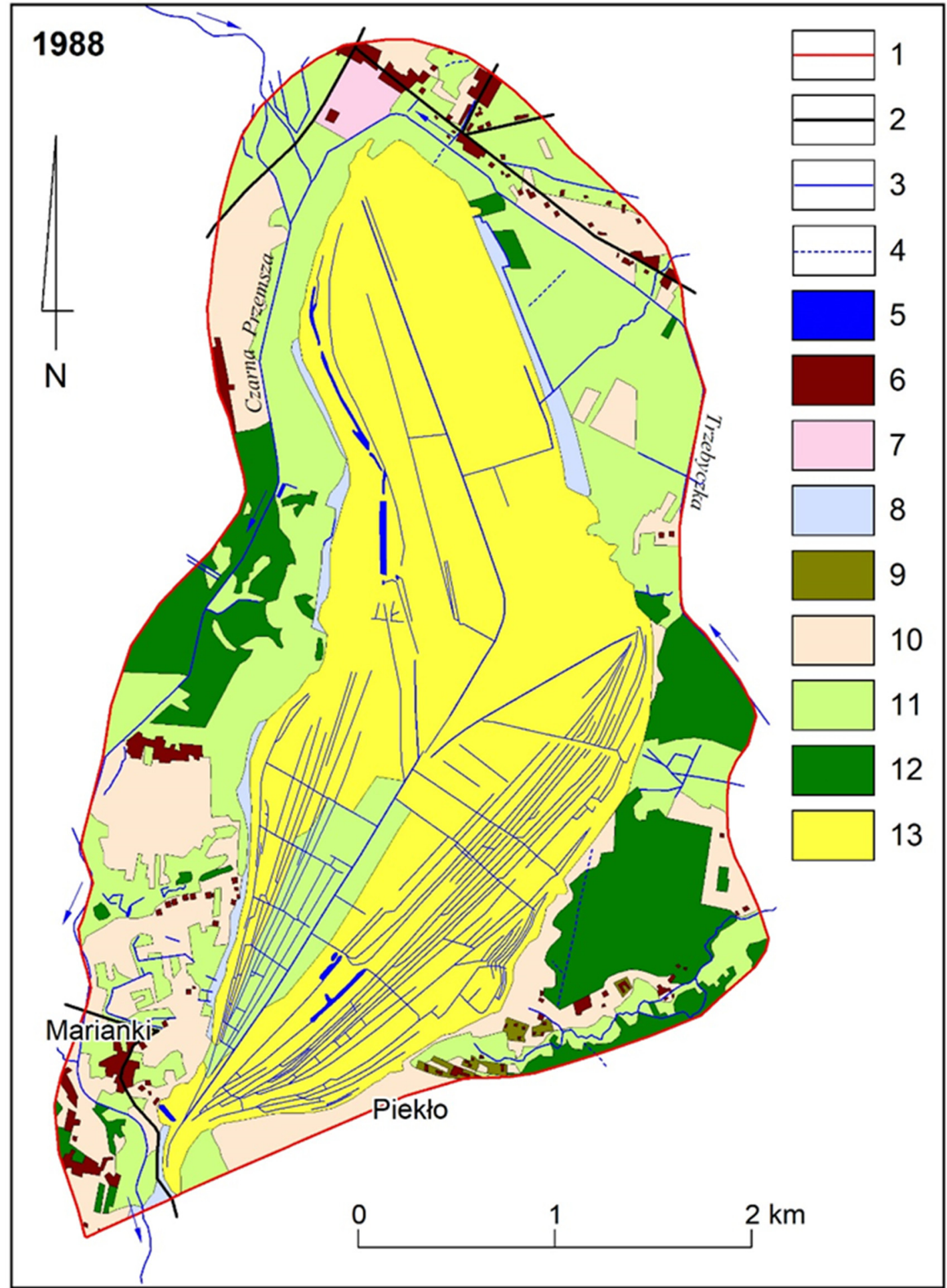

Figure 4. Changes in land use in the area of Kuźnica Warężyńska for the year 1988: 1-border of the research area, 2-important roads and railways, 3-permanent watercourses, 4-periodic watercourses, 5-water reservoirs, 6-spatial development, 7-industrial areas, 8-wastelands, 9-urban greenery, 10 - arable land, 11 — meadows and pastures, 12 —forests and trees (including parks, orchards), 13 —sand pits and sandy areas. 


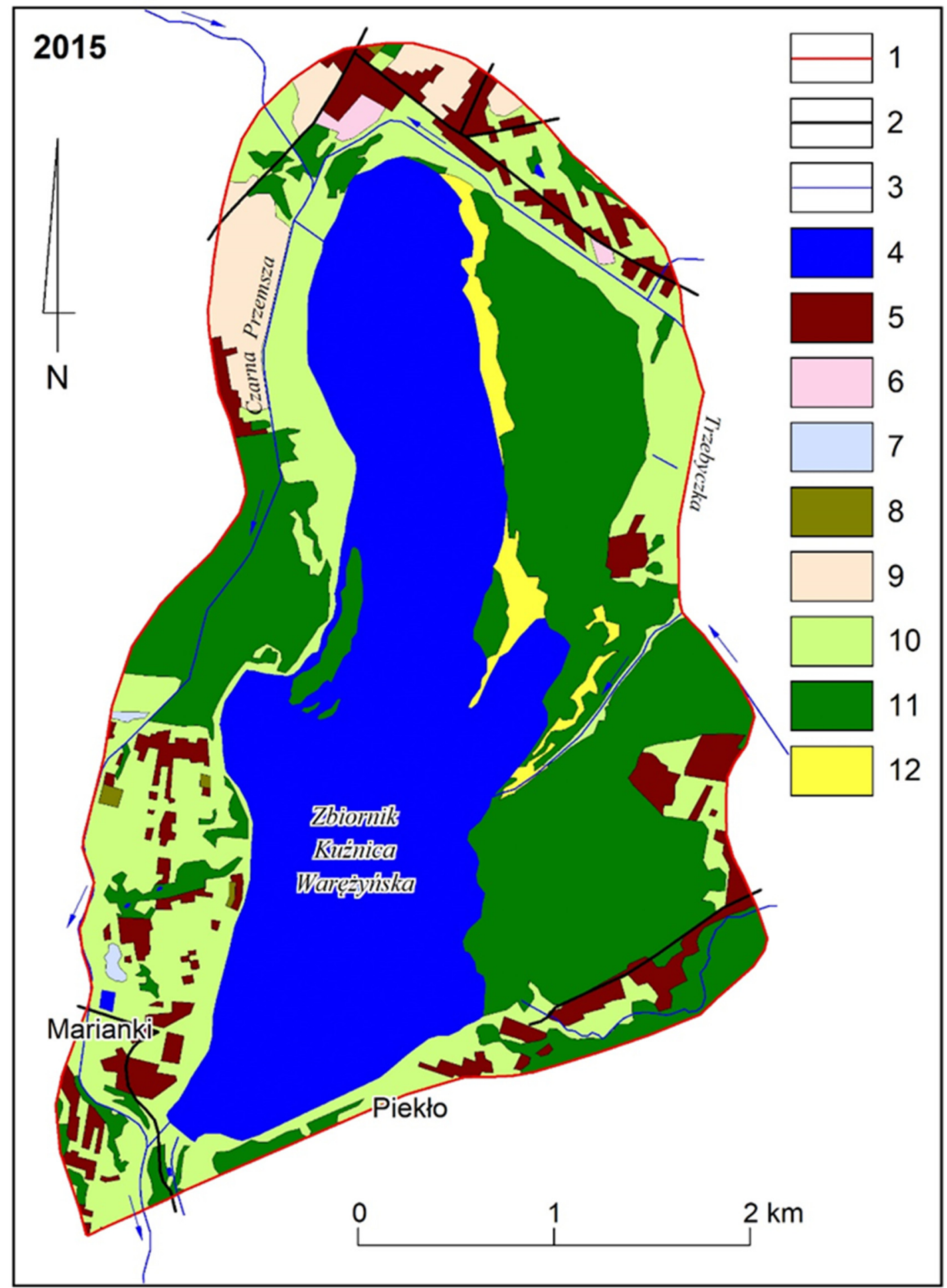

Figure 5. Land use cover in the area of Kuźnica Warężyńska for the year 2015: 1—border of the research area, 2-important roads and railways, 3-permanent watercourses, 4-water reservoirs, 5-spatial development, 6-industrial areas, 7-wastelands, 8-urban greenery, 9-arable land, 10-meadows and pastures, 11-forests and trees (including parks, orchards), 12—sand pits and sandy areas.

\subsection{Depletion of Groundwater Resources}

Prior to the extraction of the Quaternary filling sand deposit, the Main Groundwater Reservoir (Główny Zbiornik Wód Podziemnych - GZWP) No. 455 Dabrowa Górnicza with an area of $21 \mathrm{~km}^{2}$ was documented within the mining area of Kuźnica Warężyńska. The hydrogeological parameters of the 
Main Groundwater Reservoir were as follows: hydraulic transmissivity, $1.16-2.32 \times 10^{-3} \mathrm{~m}^{2} / \mathrm{s}$; average hydraulic conductivity, $1.16 \times 10^{-4} \mathrm{~m} / \mathrm{s}$; the renewable resources of groundwater reservoir amounted to $31,968 \mathrm{~m}^{3} /$ day (11.65 million $\mathrm{m}^{3} /$ year) and the resources modulus was $17.6 \mathrm{l} / \mathrm{s} / \mathrm{km}^{2}$ [40,41]. The amount of water pumped from the Kuźnica Warężyńska sand pit workings reached 45,600 m³/day (16.6 million $\mathrm{m}^{3} /$ year). For drainage of these mine waters were discharged into the Czarna Przemsza River and used for industrial purposes [41]. The reservoir area was classified as an "Area requiring maximum protection", and its water quality was classified as very slightly polluted, with only slight deviations from acceptable values, which are easy to treat. The reservoir did not have long-term potential, however. The reservoir is not isolated, had an average surface water resources as an alternative source of water (range $5-10 \mathrm{l} / \mathrm{s} / \mathrm{km}^{2}$ ) and low groundwater reserves ( $<25 \%$ of disposable resources).

In 2015, the Local Groundwater Reservoir (Lokalny Zbiornik Wód Podziemnych-LZWP) No. 455 Dabrowa Górnicza, with an area of just $5.38 \mathrm{~km}^{2}$ was established in place of the previous Main Groundwater Reservoir in the underground catchment area of the Kuźnica Warężyńska Reservoir which had an area of $20.55 \mathrm{~km}^{2}$. The reservoir was demoted from the main to the local category due to the almost fourfold reduction in its surface area and its failure to meet hydraulic transmissivity, extraction groundwater intake and water quality criteria. Currently, the maximum thickness of sandy sediments in the reservoir does not exceed $20 \mathrm{~m}$, the average hydraulic transmissivity is $1.16 \times 10^{-4} \mathrm{~m}^{2} / \mathrm{s}$ and disposable resources per unit of area amount to $1408 \mathrm{~m}^{3} / \mathrm{d} / \mathrm{km}^{2}$ [42].

\subsection{Changes in Groundwater Circulation Conditions}

The Quaternary aquifer is mainly recharged through direct rainwater infiltration. In the river valley, this source was originally limited by the presence of a 2-3 metres thick layer of Holocene organic formations (alluvial soils, peats). During the period when the operation of the Kuźnica Warężyńska sand mine exerted an impact on the area, the average infiltration of precipitation reached 44.5\% [26], and in the neighbouring Szczakowa mine it was as high as 68\% [42,43]. For the Kuźnica Warężyńska Reservoir, the average infiltration of precipitation in 2013 was calculated as ranging from 15\% to 35\% in individual catchment areas of the reservoir [44]. During extraction of the sand deposit, the flow of groundwater was directed into the mine's sump by a system of channels and ditches. The groundwater table was lowered by a few metres to a maximum of 30 metres in the central part of the opencast mine, which resulted in the formation of an asymmetrical depression cone with a reach ranging from 50 to 950 metres outside the boundaries of the mineral workings. From 1990 to 2004, the average water inflow into the mine workings was $0.345 \mathrm{~m}^{3} / \mathrm{s}$ [45]. As a result of the former workings having been flooded, the depression cone disappeared. At the same time, the role of the Czarna Przemsza River changed. Under natural conditions, it used to be the main drainage route, but currently it flows (in a similar manner to its Trzebyczka River tributary) in regulated and sealed channels and is not hydraulically connected to the groundwaters. The aquifer is now mostly drained by the Kuźnica Warężyńska Reservoir.

\subsection{Transformation of the Hydrological Conditions}

Water conditions in the area have been largely transformed by human activity. The surface hydrographic network has changed: some watercourses have disappeared or have been liquidated, gradients have been distorted by land subsidence, regulatory work has been conducted (the Przemsza, the Trzebyczka), channels have been moved (the Przemsza, the Trzebyczka), surface runoff has been obstructed in mining subsidence areas, surface retention has increased as a result of the construction of the Kuźnica Warężyńska Reservoir and mining areas have been flooded (Figures 2-5).

The Kuźnica Warężyńska flood control reservoir was constructed in former sand workings in the years 2003-2005. It is a reservoir with an area of 560 hectares, total capacity of 51.16 million $\mathrm{m}^{3}$, flood capacity of 8.07 million $\mathrm{m}^{3}$, maximum water level of $265 \mathrm{~m}$ a.s.l. and maximum depth of $23 \mathrm{~m}$. The area, which had been transformed by more than 30 years of mining activity, was reclaimed and regenerated. The Regional Water Management Board in Gliwice incorporated the Kuźnica Warężyńska Reservoir into 
the Czarna Przemsza River catchment retention system, which also includes the Przeczyce Reservoir in the north and the Pogoria III Reservoir in the south. The reservoir serves flood control functions (fourfold reduction in potential flood discharges in the Przemsza River from $\mathrm{Q}_{1 \%}=60 \mathrm{~m}^{3} / \mathrm{s}$ to $14.3 \mathrm{~m}^{3} / \mathrm{s}$ and from $Q_{0.3 \%}=80 \mathrm{~m}^{3} / \mathrm{s}$ to $19.4 \mathrm{~m}^{3} / \mathrm{s}$ ). In addition, it compensates for low discharges and allows environmental flow to be maintained in the Czarna Przemsza River. For comparison purposes: the multiannual mean annual minimum flow in the Czarna Przemsza River at gauge above the Kuźnica Warężyńska Reservoir was $0.59 \mathrm{~m}^{3} / \mathrm{s}$ and at gauge below the Kuźnica Warężyńska Reservoir it was $0.74 \mathrm{~m}^{3} / \mathrm{s}$ [26].

\subsection{Changes in Groundwater and Surface Water Chemistry}

The chemistry of waters in the study area has been characterised by considerable temporal and spatial differences conditioned by successive stages of human pressure (Table 2). Owing to the varied nature of the tests conducted (wells, mining waters, piezometers, surface waters), their results are difficult to compare. Waters flowing into the mine drainage system were characterised by a mineral content of up to $0.6 \mathrm{~g} / \mathrm{dm}^{3}$ and were of the $\mathrm{HCO}_{3}-\mathrm{SO}_{4}-\mathrm{Ca}-\mathrm{Mg}$ and $\mathrm{SO}_{4}-\mathrm{HCO}_{3}-\mathrm{Ca}-\mathrm{Mg}$ hydrochemical types. Those waters were classified as medium and low quality due to elevated concentrations of $\mathrm{SO}_{4}$, Fe and Mn [41].

Table 2. Water chemistry in the area of the Kuźnica Warężyńska excavation in the period from the first half 60 s of the 20th century to 2008 (based on [26,45]).

\begin{tabular}{|c|c|c|c|c|c|}
\hline $\begin{array}{c}\text { Hydrochemical } \\
\text { Element }\end{array}$ & $\begin{array}{c}(1) \\
\text { Groundwater } \\
\text { First Half } \\
1960\end{array}$ & $\begin{array}{c}(2) \\
\text { Groundwater } \\
\text { 1967-1968 }\end{array}$ & $\begin{array}{c}(3) \\
\text { Collective } \\
\text { Mine Water } \\
\text { 1990-2004 }\end{array}$ & $\begin{array}{c}(4) \\
\text { Groundwater } \\
2007-2008\end{array}$ & $\begin{array}{c}(5) \\
\text { Surface Water } \\
2007-2008\end{array}$ \\
\hline DR/TDS [mg/L] & $175-300^{6 /}$ & $185-548^{6 /}$ & $350-551^{6 /}$ & $148-1210$ & $310-360$ \\
\hline $\mathrm{pH}$ & $6.7-7.5$ & no data & $7.5-8.1$ & $5.01-7.20$ & $7.75-8.36$ \\
\hline $\mathrm{Ca}[\mathrm{mg} / \mathrm{L}]$ & $10-50$ & $43-115$ & no data & 18-232 & $62-75$ \\
\hline $\mathrm{Mg}[\mathrm{mg} / \mathrm{L}]$ & 3.0-15 & $7.6-32$ & no data & $3.7-64$ & $15-22$ \\
\hline $\mathrm{Na}[\mathrm{mg} / \mathrm{L}]$ & $1.0-10$ & $5-25$ & $8.0-33$ & $2.6-76$ & $13-18$ \\
\hline $\mathrm{K}[\mathrm{mg} / \mathrm{L}]$ & $0.5-3.0$ & $2-4.5$ & $2.6-6.5$ & $1.0-25$ & $3.5-5.5$ \\
\hline $\mathrm{NH}_{4}[\mathrm{mg} / \mathrm{L}]$ & $0.0-0.005$ & $0.16-0.80$ & $0.003-1.48$ & $0.02-1.0$ & $0.05-0.28$ \\
\hline $\mathrm{HCO}_{3}[\mathrm{mg} / \mathrm{L}]$ & $120-250$ & no data & no data & $9.2-518$ & $168-207$ \\
\hline $\mathrm{SO}_{4}[\mathrm{mg} / \mathrm{L}]$ & $25-50$ & $30-211$ & $71-160$ & $37-367$ & $63-79$ \\
\hline $\mathrm{Cl}[\mathrm{mg} / \mathrm{L}]$ & 10-20 & $10-42$ & 27-44 & $2.7-167$ & $12-32$ \\
\hline $\mathrm{NO}_{3}[\mathrm{mg} / \mathrm{L}]$ & $0.0-0.005$ & $0.0-0.24$ & $0.002-8.1$ & 0.0-95 & $1.5-16$ \\
\hline $\mathrm{NO}_{2}[\mathrm{mg} / \mathrm{L}]$ & $0.0-0.0002$ & $0.003-0.02$ & $0.01-0.46$ & $0.0-2.2$ & 0 \\
\hline $\mathrm{Fe}[\mathrm{mg} / \mathrm{L}]$ & $0.0-1.0$ & $2.4-12.2$ & $0.1-0.75$ & $0.02-3.4$ & $0.02-0.09$ \\
\hline $\mathrm{Mn}[\mathrm{mg} / \mathrm{L}]$ & $0.0-0.02$ & $0.39-1.46$ & $0.03-0.30$ & $0.004-0.212$ & $0.004-0.035$ \\
\hline
\end{tabular}

Note: (1) Presumed chemistry of Quaternary aquifer in the Czarna and Biała Przemsza fossil valleys before the period of mining activity; (2) the chemistry of groundwater flowing into the excavation of the "Kuźnica Warężyńska" mine in 1967-1968; (3) the chemistry of collective water pumped out of the mine in 1990-2004; (4) the chemistry of groundwater tested in 9 piezometers; (5) chemistry of water from the reservoir and from the Czarna Przemsza River in 2007-2008; (6) DR-Dry residue; TDS-Total Dissolved Solids.

The results of groundwater chemical analyses conducted from November 2007 to October 2008, i.e. shortly after the mine workings had been flooded in 2006, indicated large spatial differences in the chemical composition of waters from the Quaternary aquifer in the area of the Kuźnica Warężyńska Reservoir. These are fresh waters, and in the western part also mineral waters, weakly acidic or neutral in reaction. As concerns microcomponents, concentrations of toxic elements such as $\mathrm{Cd}$ (up to $0.045 \mathrm{mg} / \mathrm{L}$ ) and $\mathrm{Ni}$ (up to $0.12 \mathrm{mg} / \mathrm{L}$ ) are noticeable. The groundwater examined were of different chemical types, containing from two $\mathrm{SO}_{4}-\mathrm{Ca}$ up to seven ions e.g. $\mathrm{SO}_{4}-\mathrm{NO}_{3}-\mathrm{Cl}-\mathrm{HCO}_{3}-\mathrm{Ca}-\mathrm{Mg}-\mathrm{Na}$. The surface waters were fresh, weakly alkaline waters. The concentrations of the ingredients in the surface waters that were tested exhibited high stability (Table 2) [45].

On the basis of the analysis of groundwater circulation conditions in the years 1966-2008, the analysis of groundwater chemical composition and geochemical modelling results, it was found that changes in the hydrodynamic conditions in the vicinity of the Kuźnica Warężyńska sand mine resulted 
in changes in the chemistry of the Quaternary aquifer [26,45]. The formation of the depression cone enabled oxygen to access Quaternary sediments and initiate the oxidation of metal sulphides and organic matter, the dissolution of calcium carbonate and gypsum precipitation. During filling of the reservoir, Quaternary formations were hydrated, which changed oxidation-reduction conditions and triggered the following processes: Manganese oxide reduction, gypsum dissolution, bivalent iron oxidation and its precipitation in the form of oxides and hydroxides. The current spatial differences in the chemical composition of groundwaters in the Kuźnica Warężyńska mine area may be the result of the heterogeneity of the hydrogeological conditions and human pressure [26].

The assessment carried out pursuant to the Regulation of the Minister of the Environment on the method of classifying the status of bodies of surface water (Journal of Laws Dz. U. 162 item 1008, 2008) demonstrated that in 2017, the status of bodies of surface water in the study area was poor [43]. This state of affairs has been caused by the discharge of untreated and insufficiently treated wastewater, inadequate sanitation in rural and recreational areas and pollution from agricultural sources, landfill sites and rainwater. This has been a long-term phenomenon.

\subsection{Transformations of the Biotic Environment}

Before the extraction of filling sand had started, the Czarna Przemsza River flowed through two channels, of which the eastern one strongly meandered and formed multiple ox-bow lakes (Figures 2 and 3). Most meanders lost their water in wet meadows and marshes. Nowadays, wet meadows have been preserved along the Trzebyczka River. These belong to the Molinion caeruleae, Calthion palustris, Filipendulion ulmariae, Magnocaricion, Phragmition alliance, and there are also Molinio-Arrhenatheretea class complexes developing in fresher habitats. Mining activity caused significant changes in water conditions, which in turn affected the functioning of plant communities and soil quality (soil processes were altered). In the vicinity of the mineral workings, the natural course of the Czarna Przemsza River changed completely (Figure 4), because in the late 1960s (Figure 3) the three-kilometre reach of the river between Wojkowice Kościelne and Będzin was moved. Currently, it flows through a single, regulated channel (Figure 5), and there are some riparian communities on the slopes of its banks [46].

Owing to high groundwater levels, small patches of gley-podzol soils, gleysols, black earth and organic soils as well as podzolic soils developed. The distribution of vegetation and soil types in the area was determined by its morphology. Fraxino-Alnetum, Salici-Populetum complexes developed on wet patches outside the meadows mentioned above; in areas where water outflow was obstructed, the Ribeso nigri-Alnetum or Sphagno squarrosi-Alnetum community were present. In dune habitats on podzolic soils, sub-Atlantic pine forest (Leucobryo-Pinetum) developed, which functions with an almost complete species composition to this day.

Vegetation changes during the 70-year period examined were closely related to human mining activity. The greatest changes occurred at the end of the 1960s when large areas of pine forest were cut down (Figures 3 and 4). As a result of mining works, soil cover was directly degraded over a significant area as the soil layer forming the overburden over the sand deposit was removed.

The analysis of vegetation in the former workings demonstrated that the diversity of habitats within the workings results in a significant increase in species diversity there compared to the adjacent areas. During the studies conducted from 1994 to 2010, as many as 367 plant species were found in the former workings [19]. Apart from vascular plants, the former workings have become a habitat for protected bryophytes and the reservoir serves as a refuge for protected algae from the Characeae family [47]. From 1994 to 2014, a total of 202 bird species were identified there, 43 of which, including 8 breeding species (Table 3), found in Annex I of the Birds Directive [37]. Comprehensive studies of the biotic environment in post-mining areas focus on the biodiversity arising in the area of these facilities $[48,49]$. Hendrychova [20] notes that conclude that habitat development under spontaneous succession is a beneficial phenomenon for future aesthetic and ecological functions of post-mining landscapes and also their ecological conditions [50,51]. In 2011, in order to protect the 
new natural values which emerged in some of the former mineral workings, the $3 \mathrm{~km}^{2}$ "Lipienniki in the Dabrowa Górnicza" (PLH240037). Natura 2000 site was established which has been classified as a groundwater-dependent ecosystem. This ecosystem includes a unique community of transitional and low mires (Table 3), in an urban area.

Table 3. Habitats and Species Included in the Annexes of the Habitats Directive and Birds Directive (Council Directive 92/43/EEC on the Conservation of Natural Habitats and of Wild Fauna and Flora), [37,52] (changed).

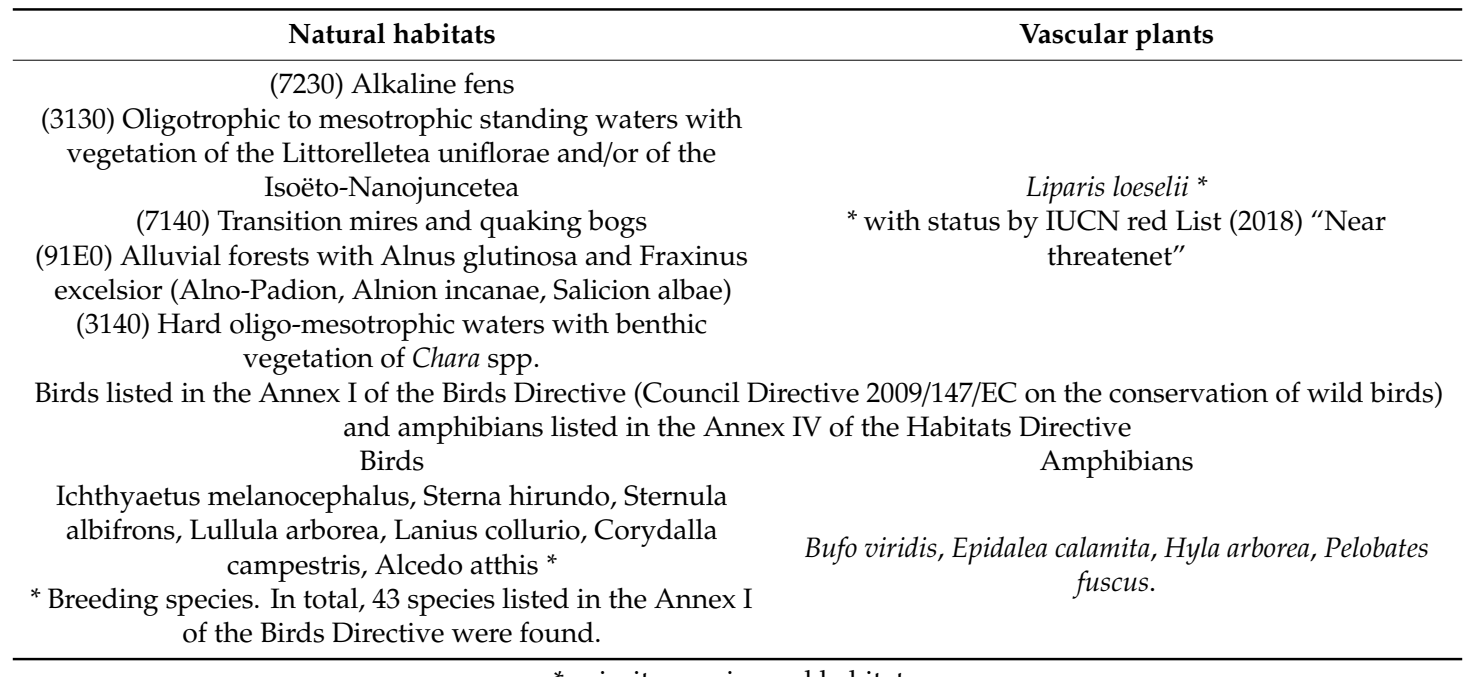

${ }^{*}$ priority species and habitat.

However, progressing natural succession, increasing pressure related to the recreational use of the reservoir and changes in the level of the water table occurring in habitats as a result of its filling have caused the withdrawal, and reduction in the population of many rare plant species. Surveys in 2010-2018 confirmed the steady evolution of habitats and demonstrated, inter alia, a significant decline in the population of rare plants such as Dactylorhiza maculata, Liparis loeselii, Malaxis monophyllos, Pinguicula vulgaris ssp. bicolor or Lycopodiella inundata and the disappearance of Carex davalliana, Huperzia selago, Malaxis monophyllos stands [52].

\section{Conclusions}

1. The article discusses environmental transformations in the area of the Kuźnica Warężyńska sand mine in southern Poland over the years 1944-2015. A comprehensive ecological analysis was carried out concerning spatial development, mining activity, hydrogeological and hydrological conditions as well as the biotic environment. During the research period, arable land was practically liquidated, and after periodic activity of sand mine in 1967-2002, a water reservoir was created in 2003-2005.

2. Mining activities and the creation of a water reservoir resulted in two times changes in groundwater circulation conditions, depletion of the aquifer due to a reduction in the surface area of the aquifer and a decrease in the value of hydrogeological parameters. The lowering of the groundwater aquifer category from regional to local. Changes in the hydrodynamic conditions have resulted in changes in the chemistry of the Quaternary aquifer, which have been manifested by periodically increased $\mathrm{SO}_{4}, \mathrm{Fe}$ and $\mathrm{Mn}$ concentrations. At the same time, the changes resulting from diverse agricultural pressures and urbanisation have been unfavourable.

3. The resulting reservoir with an area of 560 ha and a volume of 51 million $\mathrm{m}^{3}$, which is currently the groundwater drainage route, ensures the allows environmental flow and has flood control functions. At the same time, it contributes to the increase of the economic, tourist and recreational attractiveness of the area. 
4. The extraction of filling sand and the reclamation of a closed mine have various effects on the natural environment. On the one hand, it led to the destruction of primary biocenotic systems. on the other hand, the creation of a water reservoir has contributed to an increase in biodiversity and the formation of valuable phytocoenoses.

5. In conclusion, it can be stated that over 75 years of human activity had a favorable economic dimension. In the area of extensive farming, conditioned by the presence of soils with low agricultural valuation, a valuable deposit of filling sands has been exploited, and after the reclamation of the open pit in the water direction, the economic and biocenotic attractiveness of the area has increased. Such a scenario is also documented by experience from other European and world countries.

Author Contributions: “Conceptualization, J.R., O.R., A.S.; methodology, J.R., O.R.; software, O.R.; formal analysis, J.R., A.S.; investigation, J.R., O.R., A.S.; resources, J.R., O.R., and A.S.; data curation, A.S., O.R.; writing-original draft preparation, J.R., O.R. and A.S.; writing-review and editing, O.R., J.R.; visualization, O.R.; supervision, J.R.; O.R. and A.S.; project administration, J.R." All authors have read and agreed to the published version of the manuscript.

Funding: This research received no external funding.

Acknowledgments: We would like to thank Andrzej Czylok for the helpful remarks. The authors are very grateful to three anonymous reviewers for constructive comments and suggestions, thanks to which the article received its final shape.

Conflicts of Interest: The authors declare no conflict of interest. The funders had no role in the design of the study; in the collection, analyses, or interpretation of data; in the writing of the manuscript, or in the decision to publish the results.

\section{References}

1. UNEP. Global Environmental Alert Service-Sand, Rarer than One Thinks; UNEP: Athens, Greece, 2014.

2. Rivier, B.; Seguier, J. Physical and biological effects of gravel extraction in river beds. In Habitat Modification and Freshwater Fisheries; Alabaster, J.S., Ed.; Food and Agriculture Organization U.N.: Rome, Italy, 1985; pp. 131-146.

3. Ghose, M.K. Land reclamation and protection of environment from the effect of coal mining operation. Mine Technol. 1989, 10, 35-39.

4. Naveen, S.M. Environmental impact of soil and sand mining: A review. Int. J. Sci. Environ. Technol. 2012, 1, 125-134.

5. Gavrilitea, M.D. Environmental Impacts of Sand Exploitation. Analysis of Sand Market. Sustainability 2017, 9, 1118. [CrossRef]

6. Nabegu, A.B. Effect of Sand mining on Ground Water in Kano River Catchment. J. Environ. Earth Sci. 2013, 3, $81-87$.

7. Arbogast, B.F.; Knepper, D.H., Jr.; Langer, W.H. The Human Factor in Mining Reclamation; U.S. Geological Survey Circular: Reston, VA, USA, 2000; Volume 1191, pp. 1-27.

8. Damigos, D.; Kaliampakos, D. Assessing the benefits of reclaiming urban quarries: A CVM analysis. Landsc. Urban Plan. 2003, 64, 249-258. [CrossRef]

9. Kasztelewicz, Z. Rekultywacja Terenów Pogórniczych w Polskich Kopalniach Odkrywkowych; AGH: Kraków, Poland, 2010.

10. Akande, J.M.; Jimoh, B.O. Quarrying of Sand and Proposed Reclamation Method in Akure, Nigeria. Int. J. Eng. Technol. 2013, 3, 747-756.

11. Uberman, R.; Ostręga, A. Reclamation and revitalisation of lands after mining activities. Polish achievements and problems. AGH J. Min. Geoengin. 2012, 36, 285-297.

12. Yuan, J.-G.; Fang, W.; Fan, L.; Chen, Y.; Wang, D.-Q.; Yang, Z.-Y. Soil formation and vegetation establishment on the cliff face of abandoned quarries in the early stages of natural colonization. Restor. Ecol. 2006, 14, 349-356. [CrossRef]

13. Prach, K.; Ǩehounková, K.; Ǩehounek, J.; Konvalinková, J. Ecological restoration of central European mining sites: A summary of a multi-site analysis. Landsc. Res. 2011, 36, 263-268. [CrossRef] 
14. Szumacher, I.; Pabjanek, P. Temporal changes in ecosystem services in European cities in the continental biogeographical region in the period from 1990-2012. Sustainability 2017, 9, 665. [CrossRef]

15. Legwaila, I.; Lange, E. Landscape restoration and visual quality. Reclamation 2010, 11, 11-13.

16. Hronček, P. Local quarries and how to use them in geotourism. Acta Geoturistica 2015, 6, 11-20.

17. Kivinen, S. Sustainable Post-Mining Land Use: Are Closed Metal Mines Abandoned or Re-Used Space? Sustainability 2017, 9, 1705. [CrossRef]

18. Novák, J.; Konvicka, M. Proximity of valuable habitats affects succession patterns in abandoned quarries. Ecol. Eng. 2006, 26, 113-122. [CrossRef]

19. Czylok, A.; Rahmonov, O.; Szymczyk, A. Biological diversity in the area of quarries after sand exploitation in the eastern part of Silesian Upland. Teka Komisji Ochrony i Kształtowania Środowiska Przyrodniczego. Oddziat Lub. PAN 2008, 5A, 15-22.

20. Hendrychová, M. Reclamation success in post-mining landscapes in the Czech Republic: A review of pedagogical and biological studies. J. Landsc. Stud. 2008, 1, 63-78.

21. Natural Water Retention Measures. Science for Environment Policy; European Commission, EurComm DG ENV; European Commission: Brussels, Belgium, 2012; Volume 32, pp. 1-12.

22. Israel, A.L.; Lange, E.; Cripps, J. Quarry reclamation in England: A review of techniques. J. Am. Soc. Min. Reclam. 2015, 4, 55-79. [CrossRef]

23. Ostrega, A.; Uberman, R. Modes of reclamation and redevelopment-Manner of choice, classification and examples. AGH J. Min. Geoengin. 2010, 34, 445-461.

24. Malinowska, E.; Szumacher, I. Survey of recreationaluse of the Las Kabacki forest nature reserve in Warsaw (Poland). Misc. Geogr. 2013, 17, 12-18.

25. Kowalewski, Z. Actions for small water retention undertaken in Poland. J. Water Land Dev. 2008, 12, $155-167$. [CrossRef]

26. Jakóbczyk, S.; Kowalczyk, A. Chemical composition of groundwater in the area of the flooded sand pit Kuźnica Warężyńska in view of modelling investigations. Biul. PIG 2009, 436, 165-174.

27. Dulias, R. Landscape planning in areas of sand extraction in the Silesian Upland, Poland. Landsc. Urban Plan. 2010, 95, 91-104. [CrossRef]

28. Map of the Upper Silesian Industrial District; 1:25,000, Arkusz 3; Zarząd topograficzny Sztabu Generalnego; Archiwum Państwowe w Katowicach: Warszawa, Poland, 1960.

29. Topographic Map on a Scale of 1: 25,000, Sheets: 521.44 Psary, 522.33 Łazy, 531.22 Sosnowiec, 532.11 Dąbrowa Górnicza-Strzemieszyce; Główny Urząd Geodezji i Kartografii, Polskie Przedsiębiorstwo Geodezyjno-Kartograficzne: Katowice, Poland, 1988.

30. Biernat, S. Szczegółowa Mapa Geologiczna Polski; 1:50000, Arkusz M34-51C, Wojkowice; Wydywnictwo Geologiczne: Warszawa, Poland, 1957.

31. Geoportal Województwa Śląskiego 2015. Available online: https://www.orsip.pl/geoportal (accessed on 25 March 2020).

32. Paniecki, T. Problems with calibration of the detailed map of Poland in 1:25,000 published by the Military Geographical Institute (WIG) in Warsaw. Pol. Prz. Kartogr. 2014, 46, 162-172.

33. Sobala, M. Application of Austrian cadastral maps in research on land use in the middle of 19th century. Pol. Prz. Kartogr. 2012, 44, 324-333.

34. Sobala, M.; Rahmonov, O.; Myga-Piątek, U. Historical and contemporary forest ecosystem changes in the Beskid Mountains (southern Poland) between 1848 and 2014. iForest Biogeosciences For. 2017, 10, 939-947. [CrossRef]

35. Polish Hydrogeological Publications. Available online: https://www.pgi.gov.pl/psh/psh-2/polskie-publikacjehydrogeologiczne.html (accessed on 3 April 2020).

36. Mining Polish Scientific Bibliography. Available online: http://www.sitg.pl/przegladgorniczy/spiswydawniczy.html (accessed on 3 April 2020).

37. Kmiecik, P.; Gwóźdź, R.; Beuch, S. The birds of Kuźnica Warężyńska Reservoir. Ptaki Ślaska 2014, 21, 69-85.

38. Kuter, N. Reclamation of Degraded Landscapes Due to Opencast Mining, Advances in Landscape Architecture. 2013. Available online: http://www.intechopen.com/books/advances-in-landscape-architecture/reclamationof-degraded-landscapes-due-to-opencast-mining (accessed on 16 October 2017).

39. Pavloudakis, F.; Roumpos, C.; Galetakis, M. Public acceptance of surface mining projects and the determination of the marginal environmental cost. Int. J. Min. Reclam. Environ. 2012, 26, 292-308. [CrossRef] 
40. Wagner, J.; Chmura, A.; Siemiński, A. Mapa Hydrogeologiczna Polski; 1:50000, ark. Wojkowice (911); PIG-PIB: Warszawa, Poland, 1997.

41. Różkowski, A.; Chmura, A.; Siemiński, A. Użytkowanie Wód Podziemnych Górnoślaskiego Zagłębia Węglowego i Jego Obrzeżenia; Prace PIG CLIX: Warszawa, Poland, 1997.

42. Mikołajków, J.; Sadurski, A. Główne Zbiorniki Wód Podziemnych w Polsce. LZWP nr 455 Dąbrowa Górnicza (Dawny GZWP nr 455); Informator PSH PIG-PIB: Warszawa, Poland, 2017; pp. 388-389.

43. Sawicki, J. Zmiany Naturalnej Infiltracji Opadów do Warstw Wodonośnych pod Wpływem Głębokiego, Górniczego Drenażu; Wyd. Oficyna Wydawnicza Politechniki Wrocławskiej: Wrocław, Poland, 2000.

44. Kropka, J.; Jagliński, Ł. Recharging infiltration in groundwater basin of Pagoria stream and Kuźnica Warężyńska, Pogoria I, Pogoria II and Pogoria III reservioirs located in the Dąbrowska valley (Silesian Voivodship). Przegląd Górniczy 2015, 12, 124-130.

45. Kropka, J.; Banaś, B. Changes in chemical composition of groundwaters in the region of area of the "Kuźnica Warężyńska" sand pit (northern part of the Upper Silesian Coal Basin). In Hydrogeology of Urbanized and Industrialized Areas; Kowalczyk, A., Różkowski, A., Eds.; Prace WNoZ: Katowice, Poland, 2005; Volume 2, pp. 97-105.

46. Rahmonov, O.; Snytko, V.A.; Szczypek, T. Influence of melioration in natural ecological processes of a small river valley (Poland). Geogr. Nat. Resour. 2016, 37, 379-384. [CrossRef]

47. Krajewski, Ł. Przyroda piaskowni Kuźnica Warężyńska w Dąbrowie Górniczej. cz. 5. ramienice i ich zbiorowiska. Przyr. Górnego Ślaska 2011, 65, 5-7.

48. Frouz, J.; Kalcik, J.; Velichova, V. Factors causing spatial heterogeneity in soil properties, plant cover, and soil fauna in a non-reclaimed post-mining site. Ecol. Eng. 2011, 37, 1910-1913. [CrossRef]

49. Festin, E.S.; Tigabu, M.; Chileshe, M.N.; Syampunani, S.; Oden, P.C. Progresses in restoration of post-mining landscape in Africa. J. For. Res. 2019, 30, 381-396. [CrossRef]

50. Classification of Ecological Status, Ecological Potential and Chemical Status, and Assessment of the Status of River Surface Water Bodies in the Ślaskie Voivodeship for 2017. Katowice. 2018. Available online: http://www.katowice.wios.gov.pl/monitoring/informacje/stan2017/wody_pow/ocena2017.pdf (accessed on 5 April 2020).

51. Aparta, M. Impact of the exploitation of filling sand on the geographical environment of the Czarna Przemsza Valley. Geogr. Studia Diss. 1984, 8, 35-47.

52. Rahmonov, O.; Różkowski, J.; Szymczyk, A. Is the Vegetation Succession a Threat for Rare and Protected Species in a Sand Quarry? Case Study of the Kuźnica Warężyńska Sand Quarry (Southern Poland). IOP Conf. Ser. Earth Environ. Sci. 2019, 362. [CrossRef]

(C) 2020 by the authors. Licensee MDPI, Basel, Switzerland. This article is an open access article distributed under the terms and conditions of the Creative Commons Attribution (CC BY) license (http://creativecommons.org/licenses/by/4.0/). 